\title{
Can green credit policy promote green innovation efficiency of heavily polluted industries? \\ ---Empirical evidence from the China's industry ${ }^{*}$
}

\author{
$\mathrm{Su} \mathrm{Li}^{1}$, Tanfeng $\mathrm{Da}^{2}$, Weiei Cui ${ }^{3}$ and Jun Zhao ${ }^{1}$ \\ (1. School of Economics and Management,Xinjiang University,Urumqi \\ 830046, China; \\ 2. Institute of Finance,Xinjiang University of Finance and Economics, Urumqi \\ 830012,China; \\ 3.School of Big Data Application and Economics, Guizhou University of Finance and \\ Economics, Guiyang 550025, China)
}

\begin{abstract}
Green credit policy as an important tool to guide China's sustainable economic development, how to effectively play the function of capital deployment and improve the efficiency of industrial green innovation is an important issue facing the construction of ecological civilization. This paper uses China's Green Credit Guideline introduced in 2012 as a quasi-natural experiment, based on relevant panel data of industries from 2007 to 2018, uses the Super-SBM model including non-expected output to measure the green innovation efficiency of 35 industries in China, and constructs the PSM-DID model to explore how green credit policy impact on the green innovation efficiency of heavily polluted industries, the results show that : green credit policy significantly contributes to green innovation efficiency of heavily polluted industries with a lag. Further study finds that green credit policy pushes heavily polluted industries to improve green innovation efficiency by increasing financing cost and R\&D investment; meanwhile, the heterogeneity test shows that the higher the state-owned share of industry, the greater the promoted effect of green credit policy on green innovation efficiency of heavily polluted industries. Finally, in order to accelerate the implementation of green credit policy and promote the green innovation efficiency of heavily polluted industries, relevant countermeasures are proposed from three aspects: banks, enterprises and government.
\end{abstract}

Key words: green credit policy; heavily polluted industries; green innovation efficiency; financing cost; R\&D investment

\footnotetext{
This research is funded by the Western Project of National Social Science Foundation of China (19XJY018), the General Project of National Social Science Foundation of China (19BZZ039), and the Innovative Project for Doctoral Students of Xinjiang University (XJUBSCX-201918).
} 


\section{Introduction}

China's economy has achieved rapid growth since the reform and opening up,but environmental problem is also getting worse. The Fifth Plenary Session of the 18th Central Committee in China put forward the development concept of "innovation, coordination, green, openness and sharing", and made green development to be one of the future development goals, which is conducive to better respond to the challenges of resource and environmental constraints and promote the construction of ecological civilization. As the pillar industry of China's economy, the traditional and sloppy development mode in the past has caused low resource efficiency and serious environmental pollution, etc. On December 31, 2011, State Council in China issued the "Industrial Transformation and Upgrading Plan", which clearly sets green and low-carbon as the important direction of industrial transformation and upgrading, and accelerates the pace of accomplishing beautiful China. Finance is the barometer of economy, how to use financial leverage to change the traditional productive method of high energy-consuming and high polluted enterprises, accelerating green innovation and realizing industrial green transformation is an important topic worth studying at present. In recent years, China has continuously issued policies related to green credit in 2007, the Environmental Protection Bureau, the former Banking Regulatory Commission and the People's Bank in China jointly issued the "Opinions on Implementing Environmental Protection Policies and Regulations to Prevent Credit Risks", which requires financial institutions to strengthen environmental awareness and strictly implement environmental credit. The "Green Credit Guidelines" issued in 2012, which further clarified the criteria and principles of green credit for banks and put forward detailed opinions on how to carry out green credit and support the development of low-carbon recycling industries, marking the formal issuance of green credit policy. After that, the relevant departments issued "Energy Efficiency Credit Guideline", "Guidance on Building Green Financial System" and other related policies. The Fourth Plenary Session of the 19th National Congress in 2019 indicated that needing to improve policies and regulations related to green production, further develop green finance and promote green innovation. The "14th Five-Year Plan and 2035 Visionary Goals" is released in 2021, which clearly stated that China should accelerate green transformation of development, resolutely curb blind development of high polluted and high energy-consuming projects, actively develop green finance, and promote green transformation of economy.

The implementation of green credit policy marks a radical change in the traditional development concept, and both listed companies and financial institutions will face huge challenge. In the past, financial resources were more inclined to be allocated to "three high" industries, which aggravated China's overcapacity and environmental pollution, and in turn, the distortion of credit structure increased bank risks. In order to improve their green ratings, banking institutions will be more inclined to approve loans for environmentally friendly projects, the investment orientation of enterprises will be transformed into green, low-carbon and circular economy fields,so the heavily polluted enterprises may face more stringent financing constraint. A large body of papers have confirmed that financing constraint affects enterprises' innovation activities (Brown et al., 2012 ${ }^{[1]}$; Amore et al., 2013 ${ }^{[2]}$; Cornaggia et al., 2015 ${ }^{[3]}$ ), and Flammer $(2020)^{[4]}$ found that the issuance of green bonds was not a superficial "green washing " tool, but directly contributed to an increase in enterprise green innovation activities. Has the implementation of green credit policy in China had such an effect? Will enterprises switch to green innovation activities? This question is currently open to further verification. 
Technological innovation had been core research content of New economic growth theory (Romer, 1990) ${ }^{[5]}$, and technological innovation could explain economic growth and medium-term volatility in TFP (Kogan et al., 2017) [6]. Industrial enterprises play the main role in innovation activities such as R\&D investment, patent application, and transformation of results, and are the main bearer of technological innovation activities. Meanwhile, green technological innovation in industrial enterprises is integration point of innovation and green development,which can break the constraints of resource and environment and promote sustainable economic development. Regarding the relevant researches on essential connotation of green technological innovation, Brawn \& Wield (1994) ${ }^{[7]}$ firstly summarized it as a collective term of polluted control technology, recycling and regenerated technology, and cleansing technology from the perspective of environmental pollution, and Aguilera \& Ortizet $(2013)^{[8]}$ further researched on this view, arguing that green technological innovation should be extended from traditionally produced design technology of enterprise to green change of management concept. Gee \& Mcmeekin (2011) ${ }^{[9]}$ observed sensitive industry, considered that green technological innovation is the innovation that stimulates industry to achieve energy saving, emission reducing and green output by improving overall efficiency of industry from environmental perspective. Relevant scholars have systematically considered the measurement of green innovation efficiency and influencing factors while studying the connotation of green technological innovation, the measurement methods for green innovation efficiency are mainly divided into three categories: one is to measure green innovation efficiency based on a single indicator of green technological result, for example, Ghisetti \& Quatraro (2017) ${ }^{[10]}$ took enterprises' green patent application as the level of green innovation efficiency, only using single indicator not only could not fully reflect the level of green innovation efficiency, but also the result of measurement might have certain degree of error. Second is using principal component analysis and factor analysis to evaluate the efficiency of green innovation, Garia et al. (2018) ${ }^{[11]}$ constructed an evaluation index system of green innovation efficiency from four aspects: product design, production process, organization management and marketing, and used factor analysis to measure enterprise's green innovative capability. Although the principal component analysis or factor analysis method makes up shortage of single indicator, cannot reflect dynamic evolution or inner authenticity of enterprise's green innovation. Third is starting from input and output perspective, the green innovation efficiency is measured by DEA-related model, which can make up for the shortcomings of principal component analysis and factor analysis, Pedro et al. (2006) ${ }^{[12]}$ took resource consumption and pollution emission into enterprise's innovation activity, and added resource and environmental variables to common input-output efficiency model to measure green innovation efficiency; Luo et al. (2019) ${ }^{[13]}$ evaluated green innovation efficiency of strategic emerging industries in China by DEA method. Regarding influencing factors of green innovation efficiency, the existing papers have mainly studied at enterprise's aspect and government's aspect, the enterprise's aspect mainly includes financial performance, financial investment and corporate management, for example, Li (2017) [14] found that corporate profitability has a positive impact on green product innovation; Ebrahimi et al. (2017) [15] argued that SEMs improved financial performance in a turbulent market, which could provide sufficient funding for green innovation and attract innovators into the enterprise; Shu et al. (2016) ${ }^{[16]}$ concluded that green management could prioritize environmental issue from external information including government's policies, customers' voices and public interest, 
and rich information flows could expand $R \& D$ activities of enterprise and promote green innovation. The government's aspect involves two main perspectives, one of which is government's regulation and the other is government's support. For example, Yao et al. (2019) ${ }^{[17]}$ argued that environmental regulation can force heavily industrial sectors (such as oil refining, chemical manufacturing, and primary metals) to accelerate green innovation $\mathrm{R} \& \mathrm{D}$, thus enhancing their environmental legitimacy; Li et al. (2018) ${ }^{[18]}$ found that in order to achieve the goals of sustainable development and environmental protection, the government would encourage enterprises to engage in green innovation, and government R\&D funding was beneficial to efficiency of enterprises' green innovation, while green credit advocated by government was also beneficial to enhance motivation of green innovation.

Green credit policy is a market-based regulation from supply side of funds outside government by reshaping investment and financing mechanism of environment, and its essence is an important extension and innovation of traditional environmental regulation. Some scholars believe that environmental regulation is beneficial to green innovation, Porter \& Linde (1995) ${ }^{[19]}$ argued that increasing the intensity of environmental regulation was beneficial to R\&D and innovative activity of enterprise, Frondel et al. (2007) ${ }^{[20]}$ demonstrated that the more stringent environmental regulation had a greater incentive effect on green innovation of enterprise through the data of OECD countries. Other scholars believe that environmental regulation inhibits green innovation. Cropper \& Oate (1992) [21] showed that under the condition of a given resource, technology and consumer's demand, environmental regulation lead to higher cost and hindered R\&D innovation activity, and Wagner (2007) ${ }^{[22]}$ thought that environmental regulation was negatively related to green innovation by the empirical analysis based on German manufacturing enterprises. Another part of scholars believe that the impact of environmental regulation on green innovation is uncertain, Lanjouw \&Mody (1996) ${ }^{[23]}$ found that there was no significant correlation between environmental regulation and green innovation, Yuan et al. ( (2017) ${ }^{[24]}$ concluded that there was a positive U-shaped relationship between environmental regulation and innovation, namely, environmental regulation had a certain "threshold" effect on the promotion of green innovation. Green credit policy as a type of environmental regulation, What impact will its implementation have on green innovation? Most scholars believe that green credit policy can promote green innovation, Benfratello et al. (2008) ${ }^{[25]}$ used data of Italian enterprises to show that the development of bank promoted technological innovation, Nanda \& Nicholas (2014) ${ }^{[26]}$ found that banking distress during the Great Depression reduced the number and quality of corporate patents, and suggesting that credit markets did play a positive role in corporate innovation, Goetz (2019) $)^{[27]}$ and He et al. (2019) ${ }^{[28]}$ both confirmed that green credit policy significantly promoted green R\&D based on respective corporate data from the United States and China, and Hu et al. $(2021)^{[29]}$ argued that green credit policy had a positive effect on green patents of heavily polluters. A few scholars argue that green credit inhibits green innovation, Morck \& Nakamura (1999) ${ }^{[30]}$ argued that a bank-based financial system inhibited the effective flow of external finance to the most innovative areas, because banks, as creditors, preferred to avoid risk due to profitability considerations, and this bias in the credit market discouraged firms' innovative activities. Miao et al. ( 2017) ${ }^{\text {[31] }}$ argued that the development of green finance could not be achieved without the supporting force of the SME market, but the concept of green finance was not widely used among SMEs, and green credit policy largely inhibited green innovation. 
Synthesizing above papers, we can conclude that many scholars have conducted rich studies around efficiency of green innovation and the relationship between green credit and green innovation, but few paper studies the relationship between green credit and the efficiency of green innovation in heavily polluted industries. After implementation of green credit policy, commercial banks will reallocate credit resources, and heavily polluted industrial enterprises may face stricter risks of environmental litigation. Compared with non-heavily polluted industrial enterprises, heavily polluted industrial enterprises have a stronger incentive to improve "green" content of their products through innovation in order to offset negative impact of tight financial control policies on their business activities caused by environmental regulations. Therefore, this paper takes the efficiency of green innovation in heavily polluted industries as the anchor point to explore the effect of green credit policy implementation, with a view to provide empirical evidence for further optimization of green credit policy and industrial green transformation. The marginal contributions of this paper: (1) In terms of research perspective, exploring the implemented effect of green credit policy from the perspective of industrial green innovation efficiency, which expands and extends the related research on green credit policy. (2) In terms of research content, green credit policy and green innovation efficiency of heavily polluted industries are included in the same framework, and the mechanism of green credit policy to enhance green innovation efficiency of heavily polluted industries is analyzed in depth from the perspective of financing cost and R\&D investment, which enriches the direct relationship between green credit policy and green innovation efficiency in heavily polluted industries and improves its systematic analysis framework. (3) In terms of research methodology, based on the traditional industrial green innovation efficiency, energy is added as input ,and industrial wastewater, industrial waste gas and industrial solid waste emissions are added as non-expected outputs, and the Super-SBM model with non-radial non-angle and variable scale payoffs is constructed to measure the green innovation efficiency of 35 industrial industries in China, and the PSM-DID method is adopted, which can more accurately evaluate the implemented effect of green credit policy on green innovation efficiency in heavily polluted industries, which makes the research findings more reliable.

The remainder of paper is organized as follows: Part II contains theoretical analysis and research hypothesis; Part III contains research methodology; Part IV contains empirical result; Part V contains further research, mainly exploring the impact of mechanism and heterogeneity; and Part VI contains conclusions and recommendations.

\section{Theoretical analysis and research hypothesis}

2.1 Green credit policy and the efficiency of green innovation in heavily polluted industries

With the deterioration of China's ecological environment, green innovation plays an increasingly important role in the process of industrial green transformation and upgrading, and environmental regulation is the primary condition that inhibits or motivates enterprises to engage in green innovation. The traditional neoclassical theory suggests that environmental regulation will have a compliance cost effect, namely, environmental regulation will lead to an increase in the cost of polluted control and inhibit enterprises from green innovation. In contrast, the revisionist school, represented by Porter, argues that environmental regulation can stimulate enterprises to engage in innovative activities, develop green technologies, processes and products, achieve partial or complete offset of the cost caused by environmental 
regulation, and improve enterprise's competitiveness (Porter \& Linde, 1995), followed by Jaffe \& Palmer (1997) ${ }^{[32]}$, Brunneimer \& Cohen (2003) ${ }^{[33],}$ Hamamoto (2006) ${ }^{[34],}$, Yang et al. (2012) ${ }^{[35]}$ and many other scholars have proved the validity of Porter's hypothesis.

Green credit policy, as a tool for financial resource regulation, requires banks to control strictly industrial support, strengthen the credit audit of polluted enterprises, and highlight the support for green economy. As financial market supply-side factors affect the financing decision of enterprises (Faulkender \& Petersen, 2006 ${ }^{[36]}$; Lemmon \& Roberts, $2010^{[37]}$ ), if commercial banks strictly control the threshold of credit and make the environmental compliance of enterprises as an important condition for granting loans, it will increase enterprise's financing difficulty in a certain extent. At this time, facing tight green credit policy, it is not realistic for enterprises to make large-scale R\&D investment. With established limited $R \& D$ investment, it is expected that heavily polluted industrial enterprises will be more inclined to focus on the improvement of innovation efficiency. Therefore, compared to non-heavily polluted industrial enterprises, when heavily polluted industrial enterprises face tighter credit regulation standards, they are more motivated to improve the quality of green development through the path of improving innovation efficiency, and thus meet the new threshold of green credit policy. Based on the above analysis, this paper proposes the following hypothesis.

H1: After the implementation of green credit policy, compared to non-heavily polluted industries, the green innovation efficiency of heavily polluted industries will increase.

2.2 Analysis of the impact mechanism of green credit policy on green innovation efficiency in heavily polluted industries

The impact mechanism of green credit policy on green innovation efficiency in heavily polluted industries is mainly manifested in two aspects: First, it increases financing cost of heavily polluted industrial enterprises and forces them to improve green innovation efficiency. The green credit policy requires banks and other financial institutions to reduce the loans of "two high and one leftover" industries, imposes punitive high interest rates, and increases credit support to ecological industry, low-carbon industry, green industry and other industries. After the implementation of green credit policy, external financing costs will be higher if enterprises have poor performance in the management of environmental risk, the disclosure of environmental information and environmental performance (Sharfman \& Fernando, $2008^{[38]}$ ), and heavily polluted industrial enterprises will face higher financing threshold and higher financing cost due to their characteristics of high pollution and high emission(Schneider, 2008 ${ }^{[39]}$ ), in the face of high financing cost, the only way for heavily polluted industrial enterprises to effectively mitigate environmental risk and reduce environmental polluted cost is to rely on green innovation. At the same time, because the high emission of heavily polluted industrial enterprises will face greater public pressure and moral condemnation, the risk of debt default increases (Sengupta, 1998) ${ }^{[40]}$, leading banks to refuse or reduce their loans, heavily polluted industrial enterprises will be under credit constraints. In order to meet the market demand for green products, the heavily polluted industrial enterprises will be more inclined to focus on the improvement of green innovation efficiency.

Second, the green debt policy forces heavily polluted industrial enterprises to increase their R\&D investment and promotes the efficiency of green innovation. Green credit policy is actually a concrete expression of environmental regulation in 
the financial market (Berensmann \& Lindenberg, 2016) ${ }^{[41]}$, and under this financial regulation policy, the "green" performance of enterprise is included as an important criterion for financial institution to grant credit (Labatt \& Whit, 2002 ${ }^{[42]}$, Thompson \& Cowton, $2004^{[43]}$ ), therefore, it can have an "innovation compensation" effect, in other words, the high interest rate and limit of green credit make treatment cost of pollution and credit cost higher than technical investment, which forces enterprises to change their productive process or upgrade their equipment of governed pollution, and achieves the purpose of clean production, thus promoting the efficiency of green innovation. On the other hand, under the pressure of green credit policy, heavily polluted industrial enterprises will actively invest more manpower, equipment and other factors in process of production, $\mathrm{R} \& \mathrm{D}$ to improve environmental management technology and implement cleaner production in order to obtain more credit support or better loan interest rate. The increaseof $R \& D$ investment is conducive to improve green innovation efficiency(Wang, et al., 2013) ${ }^{[44]}$. Based on above analysis, this paper proposes following hypothesis.

H2: Green credit policy promotes the efficiency of green innovation by increasing financing cost and R\&D investment of heavily polluted industries.

2.3 Heterogeneity analysis of the impact of green credit policy on green innovation efficiency in heavily polluted industries

China's state-owned and private enterprises had significant difference in obtaining loan from banks for a long time. For banks, state-owned enterprises had a low probability of defaulting on their debts due to implicit government's guarantee, and tended to survive for a longer period of time, had stable banking relationships with state-owned banks, and had relatively weak information asymmetry, and thus faced lower financing constraint than private enterprises (Brandt \& Li (2003) ${ }^{[45]}$ ). At the same time, the World Bank Investment Climate Survey showed that more than $70 \%$ of China's private enterprises considered external financing constraint as the most important factor hindering private enterprises' development (Claessens \& Laeven, $\left.2003^{[46]}\right)$. Currently, most credit resources of China's financial institution were captured by state-owned enterprises, causing private enterprises to face a common credit discrimination. When the green credit policy was promulgated, private heavily polluted industrial enterprises with narrow debt financing channel were unable to maintain a high sensitivity to the implementation of policy, which led to a lack of incentive innovation. In contrast, before the implementation of policy, the share of debt financing involved in state-owned heavily polluted industrial enterprises is usually higher, leading to a greater impact of the green credit policy on them, therefore, state-owned heavily polluted industrial enterprises were more motivated to innovate (Choi, et al., 2011) ${ }^{[47]}$ and improved green innovation efficiency in response to the dividend of green credit policy. Based on above analysis, this paper proposes the following research hypothesis.

H3: The higher share of state-owned in the industrial industries, the greater contribution of green credit policy to green innovation efficiency in heavily polluted industries.

\section{Research Methodology}

\subsection{Research Model}

In this paper, the propensity score matching method (PSM-DID) is used to assess the policy effect of the impact of green credit policy on green innovation efficiency in heavily polluted industries. The core idea of the propensity score matching method (PSM-DID) is to find industry $\mathrm{j}$ in the control group to match industry $\mathrm{i}$ in the 
experimental group, namely $x_{j} \approx x_{i}$, and go to compare with each other. Compared with DID method, PSM-DID method can solve both endogenous problem and distinguish time effect formed over time from policy effect caused by implementing green credit policy. The weight is determined by kernel matching, the propensity score is estimated by Logit regression, and the effect of green debt policy on the green innovation efficiency before and after implementation is compared using double difference approach (DID). Thus, the following model (1) is constructed.

$$
G I E_{i, t}=\beta_{0}+\beta_{1} D I D+\beta_{2} \text { Pollution }+\beta_{3} \text { Greendebt }+\sum_{k=1}^{N} \beta_{k} X_{i, t}+\mu_{i}+v_{t}+\varepsilon_{i, t}
$$

where explanatory variable $\mathrm{GIE}_{\mathrm{i}, \mathrm{t}}$ denotes green innovation efficiency, which is measured by Super-SBM model with non-radial non-angular and variable payoffs of scale. The explanatory variable DID is interaction term with Greendebt and Pollution, Pollution denotes industry pollution dummy, and Greendebt denotes policy time dummy. $X_{i, t}$ are a series of control variables, including industry growth ( ${ }^{\text {Growth }}{ }^{, t}{ }$ ), fixed asset investment $\left({ }^{\text {Invest }_{i, t}}\right)$, environmental regulation ( Environment $_{i, t}$ ), etc. $\beta_{0}$ is a constant, and $\beta_{1}$ is net impact coefficient of green credit policy on green innovation efficiency in heavily polluted industries, and $\beta_{k}$ is coefficients of control variables on green innovation efficiency. In addition, ${ }^{\mu_{\mathrm{i}}}$ is industrial fixed effect, the $v_{\mathrm{t}}$ is time fixed effect, and $\varepsilon_{\mathrm{i}, \mathrm{t}}$ is random disturbance term.

The green credit policy was implemented in 2012, and in order to further examine dynamic marginal effect of green credit implementation over time, subdividing the time into 2012, 2013 and 2014 respectively on the basis of model (1), thus forming $t_{2012}, t_{2013}, t_{2014}$, the $t_{2012}=1$ denotes the year sample is located in 2012, 0 otherwise, the $t_{2013}=1$ denotes the year sample is located in 2013, 0 otherwise, and the $t 2014=1$ denotes the year sample is located in 2014, 0 otherwise. Constructing the model (2) as follows.

$$
G E_{, t}=\beta 0+\beta D D \_2012+\beta D D{ }_{2}{ }^{2013}+\beta D_{3}{ }_{2}{ }^{2014}+\sum_{k=1}^{N} \beta X_{i, t}+\mu+v_{t}+\varepsilon, t
$$

$\beta_{1}, \beta_{2}, \beta_{3}$ represent respectively marginal effects of green credit policy on green innovation efficiency in 2012, 2013, and 2014, and their values are significantly positive, indicating that green credit policy can promote the improvement of green innovation efficiency in heavily polluted industries, and the meanings of other variables are the same as model (1).

3.2 Variable description and data source

\subsubsection{Variable description}

(1) Explanatory variables $G I E_{i, t}$. Green innovation efficiency in the industry is measured by DEA model based on Li \& Zeng (2020) ${ }^{[48]}$. DEA model was a scientific method for non-parametric efficiency analysis from the relative comparison perspective of evaluated object (1978) ${ }^{[49]}$, and could be used to evaluate multiple inputs and outputs. Ordinary DEA model was divided into two categories: CCR model based on constant returns to scale (CRS), and BCC model based on variable 
returns to scale (VRS), both of which were radial in perspective. To overcome the shortcoming of ordinary DEA model, Tone (2001) ${ }^{[50]}$ proposed the SBM model to solve the problem of variable slack, but the model still could not achieve further evaluation of multiple decision effective units. To remedy this shortcoming, Tone (2002) ${ }^{[51]}$ proposed the Super-SBM model. In this paper, the Super-SBM model with non-radial non-angle and variable scale payoffs is used to measure the green innovation efficiency of 35 industries in China as follows.

$$
\begin{aligned}
& \min \rho=\frac{1+\frac{1}{m} \sum_{i=1}^{m} s_{i}^{-} / x_{i k}}{1-\frac{1}{q_{1}+q_{2}}\left(\sum_{r=1}^{q_{1}} s_{r}^{+} / y_{r k}+\sum_{r=1}^{q_{2}} s_{t}^{b-} / b_{r k}\right)} \\
& \text { s.t } \sum_{j=1, j \neq k}^{n} x_{i j} \lambda_{j}-s_{i}^{-} \leq x_{i k} \\
& \sum_{j=1, j \neq k}^{n} y_{r j} \lambda_{j}+s_{r}^{+} \geq y_{r k} \\
& \sum_{j=1, j \neq k}^{n} b_{t j} \lambda_{j}-s_{t}^{b-} \leq b_{t k} \\
& 1-\frac{1}{q_{1}+q_{2}}\left(\sum_{r=1}^{q_{1}} s_{r}^{+} / y_{r k}+\sum_{t=1}^{q 2} s t_{r}^{b-} / b_{r k}\right) \succ 0 \\
& \lambda, s^{-}, s^{+} \geq 0 \\
& i=1,2, \cdots, m ; r=1,2, \cdots, q ; j=1,2, \cdots, n(j \neq k)
\end{aligned}
$$

where $s_{i}^{-}$is the slack of the i input, $s_{r}^{+}$is the slack of the $\mathrm{r}$ output, $\lambda$ is the weight vector, and $\rho$ is the value of green innovation efficiency, with higher value reflecting higher efficiency. The input factors to measure green innovation efficiency in China's industries include labor, capital, technology and energy, among which labor input is measured by the number of people employed in industry; capital input is measured by the capital stock calculated by perpetual inventory, which is estimated by $K_{i, t}=K_{i, t-1}(1-\delta)+I_{i, t} / \lambda_{i, t}, \delta$ is the depreciation rate of $9.6 \%$ based on the research result of Zhang (2003) [52], ${ }_{i, t}$ is the net value of fixed asset investment,and $\lambda_{t}$ is the fixed asset investment index. The capital stock in 2007 is calculated as $K_{i, 2007}=I_{i, 2007} /(\delta+g), g$ is the average growth rate of fixed asset investment in each industry from 2007 to 2018. Technology input includes R\&D personnel and R\&D internal funding expenditure, where $R \& D$ internal funding expenditure is based on 2007 and deflated by the fixed asset investment index. Energy input is measured by total energy consumption. The output element include expected output and non-expected output, with expected output being gross industrial output value, patent applications and new product sale's revenue, of which gross industrial output value and new product sale's revenue is deflated by the ex-factory industrial producer price index, non-expected output includes emission of industrial wastewater, emission of industrial waste gas and emission of solid waste.

(2) The explanatory variable DID is the interaction term of Pollution and Greendebt . The green innovation efficiency before the implementation of green debt policy is $\beta_{0}+\beta_{3}$, the green innovation efficiency after the implementation of green 
debt policy is $\beta_{0}+\beta_{1}+\beta_{2}+\beta_{3}$, and the net change of green innovation efficiency is $\Delta G C_{1}=\beta_{1}+\beta_{2}$, which includes the effect of green credit policy and other policies in heavily polluted industries. Similarly, for non-heavily polluted industry, the green innovation efficiency before the implementation of green credit policy is $\beta_{0}$, the green innovation efficiency after the implementation of green credit policy is $\beta_{0}+\beta_{2}$, and the net change is $\Delta G C_{0}=\beta_{2}$, which does not include the effect of green credit policy, and the change of green innovation efficiency before and after implementation of green debt policy in the experimental group is $\triangle G C_{1}$ subtracted from the change of green innovation efficiency in the control group $\Delta G C_{0}$ to obtain $\Delta \Delta G C=\beta_{1}$,which represents the net effect of green credit policy on green innovation efficiency in heavily polluted industries, and if the implementation of green credit policy improves green innovation efficiency in heavily polluted industries, $\beta_{1}$ is significantly positive, otherwise it is negative.

(3) Industrial polluted variable Pollution, which is assigned a value of 1 when denoting the experimental group (heavily polluted industries), and 0 when denoting the control group (non-heavily polluted industries). The key of double difference method is to construct appropriate experimental group and control group. The green credit policy introduced in 2012 does not clearly define the target of policy implementation, this paper draws on Vig (2013) ${ }^{[53]}$ and Campello \& Larrain (2016) ${ }^{[54]}$ to deal with the differential impact of green credit policy on different industries in experimental group and control group, compared to non-heavily polluted industries, heavily polluted industries are more obviously affected by this policy directly, based on this, this paper selects heavily polluted industries as the experimental group and non-heavily polluted industries as the control group. For the classification of polluted industries, industrial industries are classified into heavily and non-heavily polluted industries according to the intensity of "three wastes" emission, and the specific step is as follows.

(1) The emission of pollutant per unit of output value $U E_{i j}=E_{i j} / Q, E_{i j}$ represents the emission of pollutant $j(j=1,2,3, \cdots, n)$ in the industry $i(i=1,2,3, \cdots, m), Q_{i}$ is the total output value of the industry $i$.

(2) The emission of pollutant per unit of production value is linearly normalized. $U E^{s}{ }_{i j}=\left[U E_{i j}-\min \left(U E_{j}\right)\right] /\left[\max \left(U E_{j}\right)-\min \left(U E_{j}\right)\right], U E_{i j}^{s}$ is the standardized value. $\max \left(U E_{j}\right)$ is the maximum value of pollutant $j$ in the industry $i, \min \left(U E_{j}\right)$ is the minimum value of pollutant $j$ in the industry $i$.

(3) The emission's intensity of pollutant in each industry: $\gamma_{i}=\sum_{j=1}^{n} U E_{i j}^{s}$

(4)According to the median polluted emission's intensity of 35 industries ,we go to classify, $\gamma>0.1589$ is heavily polluted industries, $\gamma<0.1589$ is non-heavily polluted industries.

(4) Policy time variable Greendebt , taking the year of 2012 when green credit policy was implemented as the standard, the year when the policy was implemented and the years after (2012-2018) are assigned a value of 1, and the years before the policy was implemented (2008-2011) are assigned a value of 0 .

(5) $X_{i, t}$ represents a series of control variables, industrial growth (Growth ${ }_{i, t}$ ), 
state-owned share (Soe $i, t)$, fixed asset investment (Invest $t_{i, t}$ ), and environmental regulation $\left(E R_{i, t}\right)$ are selected as control variables with reference to relevant studies by Kem (2015) ${ }^{[55]}$, Chen, et al. (2017) ${ }^{[56]}$, and Medeiros, et al. (2018) ${ }^{[57]}$. Industrial growth (Growth ${ }_{i, t}$ ) is measured by current operating revenue minus previous operating revenue and divide previous operating revenue; state-owned share ( $\left.\operatorname{Soe}_{i, t}\right)$ is measured by the ratio of state-owned asset to total asset; fixed asset investment ( Invest $_{i, t}$ ) is measured by total fixed asset investment; and environmental regulation $\left(E R_{i, t}\right)$ is measured by total environmental polluted control cost.

\subsection{Data source}

In this paper, the Green Credit Guidelines introduced in 2012 is used as a proxy variable for the implementation of green credit policy, and considering the matching of industrial wastewater, waste gas and solid waste emissions' data and other variables, panel data related to above-scale or large and medium-sized industrial enterprises in China from 2007 to 2018 are selected as the research sample. Owing that industrial industry changed standard principle of classification in 2012, and in order to ensure the consistency of statistical indicator, we combined the rubber industry and plastic industry, and combined the automobile transportation industry and railroad transportation industry, while industries with more missing data and inconsistency were excluded. The data were mainly obtained from China's Statistical Yearbook, China's Industrial Statistical Yearbook, China's Science and Technology Statistical Yearbook and China's Environmental Statistical Yearbook, etc. The missing values were completed by the method of linear interpolation. The descriptive statistic of variables is shown in Table 1 .

Table 1.Result of descriptive statistics of variables.

\begin{tabular}{ccccccc}
\hline Variables & $\begin{array}{c}\text { Observati } \\
\text { ons }\end{array}$ & $\begin{array}{c}\text { Average } \\
\text { value }\end{array}$ & $\begin{array}{c}\text { Standard } \\
\text { deviation }\end{array}$ & $\begin{array}{c}\text { Maximum } \\
\text { value }\end{array}$ & $\begin{array}{c}\text { Intermediat } \\
\text { e values }\end{array}$ & $\begin{array}{c}\text { Minimum } \\
\text { value }\end{array}$ \\
\hline GIE $E_{i, t}$ & 420 & 0.53 & 0.49 & 2.13 & 0.34 & 0.00 \\
DID & 420 & 0.27 & 0.45 & 1.00 & 0.00 & 0.00 \\
Pollution & 420 & 0.50 & 0.50 & 1.00 & 1.00 & 0.00 \\
Greendebt $_{\text {Growth }}, t$ & 420 & 0.54 & 0.50 & 1.00 & 1.00 & 0.00 \\
Soe $_{i, t}$ & 420 & 1.29 & 0.43 & 2.35 & 1.24 & 0.19 \\
Invest $_{i, t}$ & 420 & 31.99 & 28.09 & 99.30 & 20.32 & 0.77 \\
ER $_{i, t}$ & 420 & 0.40 & 0.36 & 1.74 & 0.28 & 0.02 \\
\hline & 420 & 0.78 & 0.14 & 0.96 & 0.79 & 0.53 \\
\hline
\end{tabular}

\section{Empirical Results}

\subsection{Balance test}

The result of balance test in Table 2 shows that after propensity score matching, the biases of industrial growth $\left(\right.$ Growth $\left.h_{i, t}\right)$, state-owned share (Soe $\left.e_{i, t}\right)$, fixed asset investment ( Invest $t_{i, t}$ ) and environmental regulation $\left(E R_{i, t}\right)$ variables are significantly reduced, and the p-values of all variables except environmental regulation $\left(E R_{i, t}\right)$ change from less than $10 \%$ to more than $10 \%$, indicating that before matching, there is a significant difference between the experimental group and the control group, and after matching, there is no significant difference between them, indicating that propensity score matching can reduce the bias caused by the heterogeneity of observable variables, which meets the criteria of propensity score in balance test and can further assess the effect of green credit policy on green innovation efficiency in 
different industries using a double difference approach.

Table 2.Result of balance test.

\begin{tabular}{|c|c|c|c|c|c|c|c|}
\hline $\begin{array}{c}\text { Variable } \\
\mathrm{s}\end{array}$ & $\begin{array}{l}\text { Match } \\
\text { Type }\end{array}$ & $\begin{array}{l}\text { Experim } \\
\text { ental } \\
\text { group }\end{array}$ & $\begin{array}{c}\text { Control } \\
\text { group }\end{array}$ & $\begin{array}{l}\text { Percentage } \\
\text { of bias (\%) }\end{array}$ & $\begin{array}{c}\text { Percentag } \\
\text { e of bias } \\
\text { reduction } \\
(\%)\end{array}$ & $\begin{array}{c}\text { Difference } \\
\text { t-value } \\
\text { between } \\
\text { the two } \\
\text { groups }\end{array}$ & $\begin{array}{l}\text { t-test } \\
\text { p-value }\end{array}$ \\
\hline \multirow[t]{2}{*}{ Growth $_{i, t}$} & $\begin{array}{l}\text { Before } \\
\text { matching }\end{array}$ & 1.2391 & 1.3608 & -28.2 & 73.2 & -2.04 & 0.043 \\
\hline & $\begin{array}{c}\text { After } \\
\text { matching }\end{array}$ & 1.2859 & 1.2533 & 7.6 & & 0.57 & 0.571 \\
\hline \multirow[t]{2}{*}{ Soe $_{i, t}$} & $\begin{array}{l}\text { Before } \\
\text { matching }\end{array}$ & 37.532 & 25.403 & 43.7 & 70.4 & 3.18 & 0.002 \\
\hline & $\begin{array}{c}\text { After } \\
\text { matching }\end{array}$ & 34.925 & 31.334 & 12.9 & & 0.94 & 0.350 \\
\hline \multirow[t]{2}{*}{ Invest $_{i, t}$} & $\begin{array}{l}\text { Before } \\
\text { matching }\end{array}$ & 4653.5 & 3157 & 43.1 & 66.6 & 3.07 & 0.002 \\
\hline & $\begin{array}{c}\text { After } \\
\text { matching }\end{array}$ & 3693.9 & 4193.9 & -14.4 & & -1.19 & 0.236 \\
\hline \multirow[t]{2}{*}{$E R_{i, t}$} & $\begin{array}{l}\text { Before } \\
\text { matching }\end{array}$ & 7696.5 & 7808.5 & -8.0 & -36.3 & -0.56 & 0.578 \\
\hline & $\begin{array}{c}\text { After } \\
\text { matching }\end{array}$ & 7694.5 & 7847.2 & -10.8 & & -0.76 & 0.447 \\
\hline
\end{tabular}

4.2. Empirical results and analysis

The result of model (1) in table 3 shows the regression result of the impact of green credit policy on green innovation efficiency in heavily polluted industries, the coefficient of DID is significantly 0.267 at the $5 \%$ level in the full sample, in order to overcome the systematic difference in the trend of green innovation efficiency between heavily polluted industries and other industries and reduce the bias of DID estimation, the PSM-DID method is used for regression analysis, the result shows that the DID coefficient is significantly 0.262 at the $1 \%$ level, and the result of PSM-DID is better overall. Both DID and PSM-DID indicate that green credit policy significantly enhances green innovation efficiency in heavily polluted industries. Hypothesis 1 is verified. The control variables of industry growth ( Growth $h_{i, t}$ ) and state-owned share $\left(S_{0 e}, t\right)$ both promote green innovation efficiency, and the coefficient of environmental regulation $\left(E R_{i, t}\right)$ is significantly positive at the $5 \%$ level, indicating that environmental regulation by government and other sectors promotes green innovation efficiency, and the effect of innovative compensation in Porter's hypothesis is brought into play.

The dynamic marginal effect of green credit policy on industrial green innovation efficiency is shown in model (2) of table 3, both for the full sample and the PSM sample, $D I D_{-} 2012$ is not significant, $D I D_{-} 2013$ and $D I D_{-2} 2014$ are significantly positive at the $1 \%$ level. The green credit policy was officially implemented on February 24, 2012, and the green credit policy began to have a significant effect on green innovation efficiency in heavily polluted industries in 2013, indicating that the effect of green credit policy on green innovation efficiency in heavily polluted industries has a time lag. 
Table 3.The result of impact and dynamic marginal effect.

\begin{tabular}{|c|c|c|c|c|}
\hline & \multicolumn{2}{|c|}{ Full sample } & \multicolumn{2}{|c|}{ PSM Sample } \\
\hline & $G I E_{i, t}(1)$ & $G I E_{i, t}(2)$ & $G I E_{i, t}(1)$ & $G I E_{i, t}(2)$ \\
\hline DID & $\begin{array}{c}0.267^{* *} \\
(2.11)\end{array}$ & & $\begin{array}{c}0.262 * * * \\
(3.97)\end{array}$ & \\
\hline Greendebt & $\begin{array}{c}0.0422 * * \\
(2.33)\end{array}$ & & $\begin{array}{c}0.0748 * * * \\
\quad(3.54)\end{array}$ & \\
\hline$D I D \_2012$ & & $\begin{array}{l}0.125 \\
(0.67)\end{array}$ & & $\begin{array}{l}0.116 \\
(0.60)\end{array}$ \\
\hline$D I D_{-} 2013$ & & $\begin{array}{c}0.444 * * * \\
(2.75)\end{array}$ & & $\begin{array}{c}0.490 * * * \\
(2.86)\end{array}$ \\
\hline$D I D \_2014$ & & $\begin{array}{c}0.230 * * * \\
(3.36)\end{array}$ & & $\begin{array}{c}0.173 * * * \\
(2.94)\end{array}$ \\
\hline Greendebt_2012 & & $\begin{array}{l}0.167 \\
(1.00)\end{array}$ & & $\begin{array}{l}0.191 \\
(1.14)\end{array}$ \\
\hline Greendebt_2013 & & $\begin{array}{c}0.188^{* *} \\
(2.22)\end{array}$ & & $\begin{array}{c}0.151^{* *} \\
(1.98)\end{array}$ \\
\hline Greendebt_2014 & & $\begin{array}{c}0.0207 * \\
(1.81)\end{array}$ & & $\begin{array}{l}0.0245^{*} \\
(1.83)\end{array}$ \\
\hline Pollution & $\begin{array}{c}0.0544^{*} \\
(1.80)\end{array}$ & $\begin{array}{c}0.0540^{* *} \\
(2.13)\end{array}$ & $\begin{array}{c}0.0641^{*} \\
(1.83)\end{array}$ & $\begin{array}{c}0.0642^{*} \\
(1.83)\end{array}$ \\
\hline Growth $_{i, t}$ & $\begin{array}{c}0.400 * * * \\
(3.90)\end{array}$ & $\begin{array}{c}0.394 * * * \\
(3.90)\end{array}$ & $\begin{array}{c}0.388^{* * *} \\
(3.80)\end{array}$ & $\begin{array}{c}0.381 * * * \\
(3.70)\end{array}$ \\
\hline $\mathrm{Soe}_{i, t}$ & $\begin{array}{c}0.00562 * * * \\
(3.52)\end{array}$ & $\begin{array}{c}0.00553 * * * \\
(3.40)\end{array}$ & $\begin{array}{c}0.00512^{* * *} \\
(3.02)\end{array}$ & $\begin{array}{c}0.00504 * * * \\
(2.92)\end{array}$ \\
\hline Invest $_{i, t}$ & $\begin{array}{c}0.236^{* *} \\
(2.45)\end{array}$ & $\begin{array}{c}0.242 * * * \\
(2.86)\end{array}$ & $\begin{array}{l}0.141 \\
(1.17)\end{array}$ & $\begin{array}{l}0.143 \\
(1.20)\end{array}$ \\
\hline$E R_{i, t}$ & $\begin{array}{c}1.002 * * \\
(2.56)\end{array}$ & $\begin{array}{l}0.763 \\
(1.55)\end{array}$ & $\begin{array}{c}1.063 * * \\
(2.47)\end{array}$ & $\begin{array}{l}0.831^{*} \\
(1.67)\end{array}$ \\
\hline _cons & $\begin{array}{l}0.394 \\
(1.29)\end{array}$ & $\begin{array}{l}0.244 \\
(0.62)\end{array}$ & $\begin{array}{l}0.484 \\
(1.31)\end{array}$ & $\begin{array}{l}0.341 \\
(0.85)\end{array}$ \\
\hline Adj_R $R^{2}$ & 0.150 & 0.153 & 0.121 & 0.125 \\
\hline $\mathrm{N}$ & 420 & 420 & 396 & 396 \\
\hline
\end{tabular}

Note: t-value in parentheses; ${ }^{*},{ }^{* *},{ }^{* * *}$ indicate significance levels of $1 \%, 5 \%$, and $10 \%$.

\subsection{Robustness test}

In order to ensure objectivity and reliability of the findings in this paper, the following two methods are used to conduct robustness test respectively. One is the robustness test using placebo method, as Green Credit Guideline was formally introduced in 2012, this paper assumes that the experimental group has implemented green credit policy in 2011, and Greendebt is 0 before 2011 and 1 from 2011 to 2018, the sample actually did not implement green credit policy, if the green innovation efficiency is caused by green credit policy, the result of placebo test in which the coefficient of DID should be insignificant. From table 4 to see, we can find that both the full sample and the PSM sample, the coefficient of DID is insignificant and passes the placebo test, indicating that double difference model satisfies common convergence condition. 
Table 4.Result of placebo test.

\begin{tabular}{ccccc}
\hline & \multicolumn{2}{c}{ Full sample } & \multicolumn{2}{c}{ PSM Sample } \\
\hline & $G I E_{i, t}(1)$ & $G I E_{i, t}(2)$ & $G I E_{i, t}(1)$ & $G I E_{i, t}(2)$ \\
DID & 0.118 & & 0.0730 & \\
& $(0.68)$ & & $(0.41)$ & 0.00418 \\
$D I D_{-} 2011$ & & 0.0266 & & $(0.02)$ \\
& & $(0.13)$ & & 0.118 \\
& & 0.134 & & $0.56)$ \\
& & $(0.66)$ & & 0.492 \\
DID_2012 & & 0.453 & & $(1.61)$ \\
& & $(1.53)$ & & 0.177 \\
DID_2013 & & 0.240 & & $(0.89)$ \\
& & $(1.29)$ & & Yes \\
Controls & Yes & Yes & Yes & 0.256 \\
cons & -0.0148 & 0.161 & -0.00241 & $(0.61)$ \\
& $(-0.05)$ & $(0.39)$ & $(-0.01)$ & 0.120 \\
Adj_R & 0.122 & 0.150 & 0.090 & 396 \\
$\mathrm{~N}$ & 420 & 420 & 396 & \\
\hline
\end{tabular}

Note: t-value in parentheses; ${ }^{*},{ }^{* *},{ }^{* * *}$ indicate significance levels of $1 \%, 5 \%$, and $10 \%$.

Second, the method of changing the width of time window is used to test whether the impact of green credit policy on green innovation efficiency with the length of the sample time, and the sensitivity of green debt policy to time change is identified by changing sample interval from 2008-2018 to 2009-2017. The result is shown in table 5, and the significance of the coefficient of DID does not change, indicating that this paper's result is robust.

Table 5.Result of changing the width of time window test.

\begin{tabular}{ccccc}
\hline & \multicolumn{2}{c}{ Full sample } & \multicolumn{2}{c}{ PSM Sample } \\
\hline & $G I E_{i, t}(1)$ & $G I E_{i, t}(2)$ & $G I E_{i, t}(1)$ & $G I E_{i, t}(2)$ \\
DID & $0.298^{* *}$ & & $0.343^{* * *}$ & \\
& $(1.97)$ & & $(3.11)$ & \\
$D I D_{-} 2012$ & & 0.139 & & 0.180 \\
& & $(0.71)$ & & $(0.87)$ \\
$D I D_{-} 2013$ & & $0.456^{* * *}$ & & $0.519^{* * *}$ \\
DID_2014 & $(2.66)$ & & $(2.79)$ \\
& & $0.213^{* * *}$ & & $0.256^{* * *}$ \\
Controls & & $(2.78)$ & & $(3.16)$ \\
cons & Yes & Yes & Yes & Yes \\
& 1.158 & -1.331 & 1.207 & -1.255 \\
Adj_R & $(1.30)$ & $(-0.78)$ & $(1.26)$ & $(-0.72)$ \\
$\mathrm{N}$ & 0.134 & 0.157 & 0.093 & 0.116 \\
& 350 & 350 & 228 & 228 \\
\hline
\end{tabular}

Note: t-value in parentheses; ${ }^{*},{ }^{* *},{ }^{* * *}$ indicate significance levels of $1 \%, 5 \%$, and $10 \%$.

\section{Further Research: Mechanism and Heterogeneity Test of Green Credit Policy on Green Innovation Efficiency in Heavily Polluted Industries}

5.1.Test of mechanism about green credit policy to promote green innovation efficiency in heavily polluted industries

From theoretical analysis of mechanism, green credit policy can promote the improvement of green innovation efficiency in heavily polluted industries, mainly due to the implementation of green credit policy increases financing cost of heavily 
polluted industrial enterprises and forces them to increase their R\&D investment, in order to verify two mechanisms, this paper constructs a mediating effect model for testing, which is divided into two steps, the first is to verify whether green credit policy increases financing cost and $R \& D$ investment in heavily polluted industries, and the second is to verify whether green credit policy, financing cost and R\&D investment increase green innovation efficiency in heavily polluted industries respectively, according to the above steps, models (3) and (4) are established as follows.

$$
\begin{aligned}
& \text { Interest }_{i, t}\left(R \& D_{i, t}\right)=\beta_{0}+\theta D I D+\sum_{k=1}^{N} \beta_{k} X_{i, t}+\mu_{i}+v_{t}+\varepsilon_{i, t} \\
& G E_{i, t}=\beta_{0}+\beta_{1} D D+\beta_{2} \text { Interest }_{i, t}(R \& D, t)+\sum_{k=1}^{N} \beta X_{i, t}+\mu_{i}+v_{t}+\varepsilon_{i, t}
\end{aligned}
$$

Interest ${ }_{i, t}$ represents interest expense, and $R \& D_{i, t}$ represents $\mathrm{R} \& \mathrm{D}$ investment. If $\theta$ is significantly positive in model (3), it indicates that green credit policy could increase financing cost and $\mathrm{R} \& \mathrm{D}$ investment in heavily polluted industries. Compared $\beta_{1}$ in model (4) with $\beta_{1}^{\prime}$ in model (1), if $\beta_{1}^{\prime}{ }_{1} \beta_{1}$, and the coefficients $\beta_{2}$ of financing cost and R\&D investment are significantly positive, it indicates that green credit policy improves green innovation efficiency in heavily polluted industries by testing the above two effects.

Table 6.Test Result of mediation mechanism of financing cost.

\begin{tabular}{ccccc}
\hline & \multicolumn{2}{c}{ Full sample } & \multicolumn{2}{c}{ PSM Sample } \\
\hline & Interest $_{i, t}(3)$ & GIE $E_{i, t}(4)$ & Interest $_{i, t}(3)$ & $G I E_{i, t}(4)$ \\
DID & $0.205^{* * *}$ & $0.253^{* *}$ & $0.187^{* * *}$ & $0.212^{*}$ \\
& $(4.69)$ & $(1.97)$ & $(3.98)$ & $(1.69)$ \\
Interest $_{i, t}$ & & $0.249^{*}$ & & $0.231^{*}$ \\
& & $(1.89)$ & & $(1.72)$ \\
Controls & Yes & Yes & Yes & Yes \\
cons & $0.170^{* * *}$ & 0.428 & $0 . .185^{* * *}$ & 0.413 \\
& $(7.47)$ & $(1.18)$ & $(7.34)$ & $(1.06)$ \\
Adj_R & 0.091 & 0.155 & 0.073 & 0.146 \\
$\mathrm{~N}$ & 420 & 420 & 396 & 396 \\
\hline
\end{tabular}

Note: t-value in parentheses; ${ }^{*},{ }^{* *},{ }^{* * *}$ indicate significance levels of $1 \%, 5 \%$, and $10 \%$.

Table 7.Test Result of mediation mechanism of R\&D investment.

\begin{tabular}{ccccc}
\hline & \multicolumn{2}{c}{ Full sample } & \multicolumn{2}{c}{ PSM Sample } \\
\hline & $R \& D_{i, t}(3)$ & $G I E_{i, t}(4)$ & $R \& D_{i, t}(4)$ & $G I E_{i, t}(4)$ \\
$D I D$ & $0.118^{* * *}$ & $0.264^{* *}$ & $0.212^{*}$ & $0.260^{* *}$ \\
& $(2.98)$ & $(2.11)$ & $(1.69)$ & $(2.00)$ \\
$R D_{i, t}$ & & $0.308^{* *}$ & & $0.573^{* * *}$ \\
& & $(2.07)$ & & $(3.16)$ \\
Controls & Yes & Yes & Yes & Yes \\
cons & $0 . .^{* * *}$ & 0.373 & 0.413 & 0.449 \\
& $(7.28)$ & $(1.23)$ & $(1.06)$ & $(1.45)$ \\
Adj_R $\mathrm{R}^{2}$ & 0.036 & 0.164 & 0.146 & 0.161 \\
$\mathrm{~N}$ & 420 & 420 & 396 & 396 \\
\hline
\end{tabular}

Note: t-value in parentheses; ${ }^{*},{ }^{* *},{ }^{* * *}$ indicate significance levels of $1 \%, 5 \%$, and $10 \%$.

The result of mechanism test of financing cost is shown in table 6 . In the 
mechanism of financing cost, the effect of green credit policy on financing cost both in the full sample and PSM sample is significantly positive at the $1 \%$ level, indicating that green credit policy increases the financing cost of heavily industrial enterprises. The effect of financing cost (Interest $t_{i, t}$ ) on green innovation efficiency $\left(G I E_{i, t}\right.$ ) is significantly positive at the $10 \%$ level, and the coefficient of DID is reduced, indicating that green credit policy pushes back heavily polluted industrial enterprises to promote green innovation efficiency by increasing their financing cost. The result of mechanism test of R\&D investment is shown in table 7, both the effect of green credit policy on $\mathrm{R} \& \mathrm{D}$ investment $\left(R \& D_{i, t}\right)$ and the effect of $\mathrm{R} \& \mathrm{D}$ investment $\left(R \& D_{i, t}\right)$ on green innovation efficiency $\left(G I E_{i, t}\right)$ under the full sample and PSM sample are significantly positive at both, indicating that there is a mediating effect of $\mathrm{R} \& \mathrm{D}$ investment. In summary, hypothesis 2 is verified.

5.2. Heterogeneity test of the effect of green credit policy on green innovation efficiency in heavily polluted industries

In order to make the analysis more in-depth, this paper further considers the influence of state-owned heterogeneity on green innovation efficiency. We add the interaction term of green credit policy and state-owned share to model (1) for verifying the influence of state-owned heterogeneity on green innovation efficiency, as follows.

$$
G I E_{i, t}=\beta_{0}+\beta_{1} D I D \times S_{b e}, t+\sum_{k=1}^{N} \beta_{i} X_{i, t}+\mu_{i}+v_{t}+\varepsilon_{i, t}
$$

In model (5), $D I D \times S o e_{i, t}$ is the interaction term of green credit policy and state-owned share, which is used to examine the effect of state-owned share on green innovation efficiency in heavily polluted industries, and sample is divided into two sub-samples according to the median of heterogeneity variable ,and to test the degree of effect on green innovation efficiency .

Table 8.Result of Heterogeneity Test.

\begin{tabular}{|c|c|c|c|c|c|c|}
\hline & \multirow[b]{2}{*}{$\begin{array}{c}\text { Full } \\
\text { sample }\end{array}$} & \multirow[b]{2}{*}{$\begin{array}{c}\text { PSM } \\
\text { Sample }\end{array}$} & \multicolumn{2}{|c|}{ High state-owned share } & \multicolumn{2}{|c|}{ low state-owned share } \\
\hline & & & $\begin{array}{c}\text { Full } \\
\text { sample }\end{array}$ & $\begin{array}{c}\text { PSM } \\
\text { Sample }\end{array}$ & Full sample & $\begin{array}{c}\text { PSM } \\
\text { Sample }\end{array}$ \\
\hline & $G I E_{i, t}(5)$ & $G I E_{i, t}(5)$ & $G I E_{i, t}(5)$ & $G I E_{i, t}(5)$ & $\left.G I E_{i, t} 5\right)$ & $G I E_{i, t}(5)$ \\
\hline$D I D \times S_{o e} e_{i, \imath}$ & $\begin{array}{c}0.005^{* *} \\
(2.57)\end{array}$ & $\begin{array}{c}0.005^{* *} \\
(2.20)\end{array}$ & & & & \\
\hline$D I D$ & & & $\begin{array}{c}0.365 * * * \\
(3.48)\end{array}$ & $\begin{array}{c}0.337 * * * \\
(4.10)\end{array}$ & $\begin{array}{c}0.240 * * \\
(2.20)\end{array}$ & $\begin{array}{c}0.285 * * \\
(2.31)\end{array}$ \\
\hline Controls & Yes & Yes & Yes & Yes & Yes & Yes \\
\hline _cons & $\begin{array}{l}0.265 \\
(0.92)\end{array}$ & $\begin{array}{l}0.301 \\
(1.03)\end{array}$ & $\begin{array}{l}-0.036 \\
(-0.08)\end{array}$ & $\begin{array}{l}0.450 \\
(1.53)\end{array}$ & $\begin{array}{c}0.485^{*} \\
(0.95)\end{array}$ & $\begin{array}{l}0.539 \\
(1.03)\end{array}$ \\
\hline $\operatorname{Adj}_{-} \mathrm{R}^{2}$ & 0.121 & 0.109 & 0.255 & 0.128 & 0.203 & 0.163 \\
\hline $\mathrm{N}$ & 420 & 396 & 420 & 198 & 420 & 198 \\
\hline
\end{tabular}

Note: t-value in parentheses; ${ }^{*},{ }^{* *},{ }^{* * *}$ indicate significance levels of $1 \%, 5 \%$, and $10 \%$.

As shown in table 8 , the coefficient of $D I D \times S_{0 e}, t$ is significantly positive, indicating that the greater state-owned share in industrial industries, the greater effect of green credit policy on green innovation efficiency, and hypothesis 3 is verified. Meanwhile, the sample is divided into two sub-samples according to the median of the state-owned share, and the sub-samples are tested separately. Observing table 9, it is found that the higher state-owned share, the greater the coefficient of 
DID, namely, the greater the enhanced effect of green credit policy on green innovation efficiency in heavily polluted industries, and this result is basically consistent with the result of regression of interaction term $D I D \times S_{0 e}, t$.

\section{Conclusions and Recommendations}

This paper constructs a quasi-natural experiment using the Green Credit Guideline introduced in 2012 as an event, measures the green innovation efficiency of 35 industries in China using a Super-SBM model with non-radial non-angular variable payoffs of scale, and empirically tests the effect of green credit policy on green innovation efficiency in heavily polluted industries by double difference and PSM-DID methods. The findings show that: first, green credit policy significantly contributes to green innovation efficiency in heavily polluted industries, and at the same time, green credit policy has a significant lag in improving green innovation efficiency in heavily polluted industries. Second, the mechanism test indicates that green credit policy pushes heavily polluted industries to improve their green innovation efficiency by increasing their financing costs and R\&D investment. Third, the heterogeneity test indicates that the higher the state-owned share of heavily polluted industries the greater the role of green credit policy in improving green innovation efficiency.

Based on the findings of this paper, in order to accelerate the pace of green credit policy implementation and improve green innovation efficiency in heavily polluted industries, the following three suggestions are made: (1) Banks should accelerate the pace of green credit policy implementation and guide heavily polluted industrial enterprises to carry out green innovation, because of the long-term business relationship between banks and industrial enterprises and the heavy social responsibility of industrial enterprises, it is more difficult for banks to change the direction of credit in a relatively short period of time.Banks can guide heavily industrial enterprises to carry out technological transformation through credit, promote green innovation, and reduce the polluted emission of enterprises. (2) The heavily polluted industries should raise awareness of environmental protection and innovation, change traditional produced methods, continuously improve the level of green innovation, reduce the emission of pollution and strengthen the construction of ecological civilization. (3) The government should encourage heavily polluted industrial enterprises to carry out green innovation, especially for the state-owned enterprises' guidance and supervision, so that they can improve their cleanliness and achieve green economic development by means of green innovation.

\section{References}

[1] Brown,J.R.; Martinsson,G.; Petersen,B.C. Do financing constraints matter for R\&D? European Economic Review.2012,56,1512-1529.

[2] Amore,M.D.; Schneider,C.; aldokas,A. Credit supply and corporate innovation. journal of financial economics.2013,109,835-855.

[3] Cornaggia,J.; Mao,Y.; Tian,X. ,et al..Does banking competition affect innovation? Journal of Financial Economics.2015,115, 189-209.

[4] Flammer,C.,2020. corporate green bonds.Journal of Financial Economics,Forthcoming,available at SSRN: https://ssrn.com/abstract=3125518. 
[5] Romer,P.M.Endogenous technological change.Journal of Political Economy.1990,98,S71-S102

[6] Kogan,L.; Papanikolaou,D.; Seru,A. ,et al. Technological innovation, resource allocation, and growth.The Quarterly Journal of Economics.2017, 132,665-712.

[7] Brawne, Wield D. Regulation as a means for the social control of technology. technology analysis and strategic management. 1994,3,498 -504.

[ 8 ]Aguilera-Caracuelj;Ortiz-De-Mandojanan.GreenInnovation and Financial Performance:Aninstitutional Apovationl Approach.Organization\&amp Organization\&amp;Environment,2013,26,365-385.

[9] Gee,S.; Mcmeekin,A. Eco-innovation systems and problem sequences:The contrasting cases of US and brazilian biofuels.Industry\&Innovation. Industry\&Innovation. 2011, 18,301-315.

[10] Ghisetti,C; Quatraro,F. Green technologies and environmental productivity: a cross-sectoral analysis of direct and indirect effects in Italian regions. Ecological Economics. 2017,132, 1-12.

[ 11 ] Garcia-Granero,Eva M.; Piedra-Muoz,Laura; Galdeano-Gomez Emilio.Eco-innovation Measurement:A Review of Firm Performance Indicators.Journal of Cleaner Production. 2018,191,304-317.

[12] Pedro, C.; M. V. Heitor; P. S. Vieira. Are Environmental Concerns Drivers of Innovation? Interpreting Portuguese Innovation Data to Foster Environmental Foresight. Technological Forecasting\& Social Change. 2006,73,266-276.

[13] Luo,Q.; Miao,C.; Sun,L,et al. Efficiency evaluation of green technology innovation of China's strategic emerging industries:An empirical analysis based on Malmquis -data envelopment analysis index.Journal of Cleaner Production. 2019,238:1 -10.

[14]Li,D.; Zheng,M.; Cao,C. , et al. The impact of legitimacy pressure and corporate profitability on green innovation: Evidence from China top 100. Journal of Cleaner Production. 2017, 141,41-49.

[15] Ebrahimip; Mirbargkar,S. M. Green entrepreneurship and green innovation for SME development in market turbulence.Eurasian Business Review. 2017, 7, 1-26.

[16] Shu,C.; Zhou,K. Z.; Xiao,Y., et al. How green management influences product innovation in China: The role of institutional benefits. Journal of Business Ethics. 2016, 133,471-478.

[17] Yao,Q.; Zeng,S.; Sheng,S.,et al. Green innovation and brand equity: Moderating effects of industrial institutions. Management. 2019, 6,1-30.

[18] Li,Z.; Liao,G.; Wang,Z.,et al. Green loan and subsidy for promoting clean production innovation.Journal of Cleaner Production, 2018, 187, $421-431$.

[19] Porter,M. E.; Van,Der. Linde C. Toward a New Concep- tion of the Environment-Competitiveness Relationship. journal of Economic Perspectives. 1995, 9,97-118.

[ 20 ]Frondelm,Horbach,J.;Rennings,K. End-of-pipe or cleaner production an empirical comparison of environmental innovation decisions across OECD countries. business strategy and the environment. 2007,16,571-584.

[21] Cropper,M. L; Oates,W. E. Environmental economics: A survey. Journal of Economic Literature. $1992,30,675-740$.

[22] Wagner,M. On there lationship between environmental management, environmental innovation and patenting: evidence from German manufacturing Research policy. 2007, 10,1587-1602.

[23] Lanjouw, J. O.; Mody, S. Innovation and the international diffusion of environmentally responsive technology.Research policy. 1996,25,549-571.

[24] Yuan, B. L.; Ren, et al. Can environmental regulation promote the coordinated development of economy and environment in China's manufacturing industry?-A panel data analysis of 28 sub-sectors.Journal of Cleaner Production. 2017,149,11-24. 
[25] Benfratello,L.; Schiantarelli,F.; Sembenelli,A. Banks and innovation: micro-econometric evidence on Italian firms.Journal of Financial Economics. 2008, 90,197-217.

[26] Nanda,R.; Nicholas,T. Did bank distress stifle innovation during the great depression? Journal of Financial Economics.2014,114,273-292.

[27] Goetz,M. Financing conditions and toxic emissions.SAFE Working Paper Series, 2019.

[28]He,L.; Zhang,L.; Zhong,Z.; Wang,D.; Wang,F. Green Credit, Renewable Energy Investment and Green Economy Development. journal of Cleaner Production.2019,208,363-372.

[29]Hu,G.; Wang,X.; Wang,Y. Can the green credit policy stimulate green innovation in heavily polluting enterprises? Evidence from a quasi-natural Energy Economics. 2021, 98,105134.

[30] Morck,R.; Nakamura,M. Banks and corporate control in Japan. the Journal of Finance.1999,54,319-339.

[31] Miao,C.; Fang,D.; Sun,L. Natural resources utilization efficiency under the influence of green technological innovation.Resources, Conservation\&Recycling.2017,126.

[32] Jaffe,A. B.; Palmer,K. Environment regulation and innovation: a panel data Study.Review of Economics and Statistics. 1997,79,610-618.

[33] Brunnermer,S.; Cohen,M. Determinants of environmental innovation in US manufacturing industries. journal of environmental economics and management. Management. 2003,45,278-293.

[34] Hanamoto,M. Environmental regulation and the productivity of Japanese manufacturing industries.Re-source and Energy Economics. 2006,28,299 - 312.

[35] Yang,C. H.; Tseng,Y. H.; Chen,C. P. Environmental regulations, induced R\&D, and productivity: Evidence from Taiwan's Resource and Energy Economics. 2012,34,514-532.

[36] Faulkender, M.; M. A. Petersen. Does the Source of Capital Affect Capital Structure? Review of Financial Studies.2006,19,45-79.

[37] Lemmon, M.; M. R. Roberts. The Response of Corporate Financing and Investment to Changes in the Supply of Credit. journal of Financial and Quantitative Analysis.2010,45,555-587.

[38] Sharfman,M.; Fernando,C. S. Environmental Risk Management and the Cost of Capital. Strategic Management Journal.2008,29:569-592.

[39] Schneider, T. E. Is there a relation between the cost of debt and environmental performance? An empirical investigation of the U.S. Pulp and Paper Industry, 1994-2005.

[40] Sengupta. corporate disclosure quality and the cost of debt. accounting Review. 1998,73,459-474.

[41] Berensmann,K; Lindenberg,N. Green Finance: Actors, Challenges and Policy Recommendations. 2016.

[42] Labatt,S.; White,R.R. Environmental Finance: A Guide to Environmental Risk Assessment and Financial Products. transplantation. 2002,66,405 9.

[43] Thompson, P.; Cowton, C. J. Bringing the Environment into Bank Lending:Implications for Environmental Reporting. British Accounting Review.2004, 36:1-218.

[44] Wang,C. H.; Lu,Y. H.; Huang,C. W.; Lee,J. Y. R\&D, productivity, and market value: An empirical study from High-technology firms. omega.2013,41, 143-155.

[45] Brandt,L.; Li,H. Bank discrimination in transition economies: ideology, information, or incentives? Journal of Comparative Economics.2003,31,87-413.

[46] Claessens, S.; Laeven, L. Financial Development, Property Rights, and Growth. Journal of Finance. 2003, $58,2401-2436$.

[47] Choi,S. B.; Lee,S. H.; Williams,C. Ownership and firm innovation in a transition economy: Evidence from China. research Policy. 2011, 40, 441-452.

[48] LI,D.; Zeng,T.Are China's intensive pollution industries greening? An analysis based on green innovation efficiency.Journal of Cleaner Production. 2020,59:120-901. 
[49] Charnes,A.; Cooper,W. W.; Rhodes,E. Measuring the efficiency of decision making units. European Journal of Operational Research. 1978,2, 429-444.

[50]Tone, K. A slacks-based measure of efficiency in data envelopment analysis. European Journal of Operational Research. 2001,130,498- 509.

[51] Tone,K. A slacks-based measure of super-efficiency in data envelopment analysis. European Journal of Operational Research. 2002,143,32-41.

[52] Zhang,J. Investment, Investment Efficiency and Economic Growth in China.Journal of Asian Economics.2003,14,713-734.

[53] Vig, V. Access to Collateral and Corporate Debt Structure: Evidence from a Natural Experiment. Journal of Finance.2013,68,881-928.

[54]Campello,M.; Larrain,M. Enlarging the Contracting Space:Collateral Menus, Access to Credit, and Economic Activity.Review of Financial Studies.2016,29,349-383.

[55] Kern,F. Engaging with the politics, agency and structures in the technological innovation systems approach. environmental Innovation and Societal Transitions. 2015,16,67- 69.

[56] Chen,L. T.; Zhang,Q.; Sun,J. S. Mechanism of Enterprise Green Innovation Process under Institutional Void and Fragility: a Multi - case Study. Journal of Advanced Management Science,2017,4,306-312.

[57] Medeiros,J.F.; Vidor,G.; Jose,Luis; Duarte Ribeiro.Driving factors for the success of the green innovation market: a relationship system proposal . Journal of Business Ethics. 2018, 147,327-341. 